\title{
COMPARATIVE ANALYSIS OF TAX PAYER'S ACCEPTANCE TO USE THE E-FILING SYSTEM
}

\author{
Annisa Hakim Zamzami ${ }^{1}$ \\ ${ }^{1}$ Assistant Professor, \\ Department of Accounting, \\ Universitas Mercu Buana, \\ Jakarta, \\ Indonesia
}

\author{
Abdul Hadi Zulkafli ${ }^{2}$ \\ ${ }^{2}$ Senior Lecturer, \\ School of Management, \\ Universiti Sains Malaysia, \\ Penang, Malaysia
}

Article DOI: https://doi.org/10.36713/epra4236

\begin{abstract}
Development inequality in terms of culture, economy, and technology in Indonesia affects the quality of human resources, can affect the system of e-filing in tax reporting which is still 70 percent in 2017. The implementation of e-filing is still related to using e-filing in tax reporting. Thus this study will examine the difference in taxpayer acceptance of the factors that influence the personal taxpayer's behavioral intentions to report tax using E-filing based on the basic theory developed by Vencatesh et al. (2003), namely the Unified Theory of Acceptance and Use of Technology (UTAUT). Thus this study aims to differences analysis taxpayer acceptance to use e-filing systems on Java and outside Java. This study analysis with T test, SPSS 25. The results state that there is no significant difference between taxpayers in Java and outside Java in accepting efiling as an online tax reporting system from performance expectancy, effort expectancy, social influence, facilitating conditions, and behavioral intention. Thus, inequality of development and internet services can be felt by all taxpayers throughout Indonesia.
\end{abstract}

KEYWORDS: $e$-filing, UTAUT Theory, taxpayer, development inequality.

\section{INTRODUCTION}

Indonesia is an archipelago consisting of 17,508 islands including 5 large islands, 34 provinces, 300 ethnic groups, 1,340 ethnic groups (Indonesia.go.id). This is that Indonesia has a high level of diversity. Thus efforts to balance state facilities in each province are also very large. In fact until now development in Indonesia is still unequal and focused on Java (Rosmeli and Nurhayani, 2014). One effort to balance Indonesia's development is to organize regional autonomy with the support of Law no. 32 of 2004 concerning Regional Government which is quite fundamental, namely the management of regional finance or fiscal independence. In fact, until 2009 regional independence was still not realized (Prastiwi et al., 2014). Rosmeli and Nurhayani, 2014 added that inequality in Java was caused by infrastructure that had an impact on economic activity and affected per capita income such as the cities of Jakarta and Surabaya. In addition, it will improve the quality of education and public health in Java, which has an impact on the quality of human resources. As stated in social cognitive theory that changes in social life, economics, and technological development will improve individual qualities from previous lives (Bandura, 1989).

Currently technological innovations continue to develop in various sectors, including in government services including Indonesia. Indonesia has decided to implement tax submission electronically, since the issuance of the DGT Decree No. KEP-88 / PJ / 2004 on May 14, 2004 concerning Submission of Electronic Notification. Then on January 12, 2005 the Directorate General of Taxes issued a decree No. KEP-05 / PJ / 2005 concerning Procedures for Submitting Electronic Tax Returns (e-filing) through Application Service Provider Companies. E-filing is a system of achieving tax online. The use of e-filing itself is very useful to ease the work process from manual to system based. This will provide better, more comfortable, friendlier, easier, more efficient, and less complicated services (Ngadiman, 2008). However, the tax submission using e-filing until 2017 has not been fully implemented. This was stated by the Director of Counseling, Service and Public Relations of the Indonesian Directorate General of Taxes Hestu Yoga (Suara electronic newspaper, 09 
March 2018) that in 2017 the public submitted tax using efiling still 60 percent.

This shows that the acceptance of the use of the e-filing system for the community is still ongoing in all regions of Indonesia. Vencatesh et al (2003) explained that several models theoretically have been used to investigate the determinants of the acceptance of new technologies, such as the Theory of Reasoned Action (TRA) applied to the Technology Acceptance Model (TAM), which explains user acceptance of information systems consisting of Perceived Usefulness, perceived ease of use, attitude, behavioral intention, behavior to use. But in its development Vencatesh et al (2003) developed the new TAM model into the Unified Theory of Acceptance and Use of Technology (UTAUT).

Unified Theory of Acceptance and Use of Technology (UTAUT) describes the user acceptance of information systems combined from eight previous theories, such as Theory of Reasoned Action (TRA), Tecnology Acceptance Model (TAM), Theory of Planned Behavior (TPB), combination of TAM and TPB models, Motivational Model (MM), Model of PC Utalization (MPCU), Innovatin of Diffusion Theory (IDT), and Social Cognitive Theory (SCT).

Vencatesh et al (2003) have examined the factors in the Unified Theory of Acceptance and Use of Technology which consist of performance expectations, effort expectancy, social influence, facilitating conditions, attitude toward using technology, self-efficacy, anxiety and behavioral intention in four organizations for six months from three types of measurements. The findings of Vencatesh et al. (2003) show that only performance expectations, effort expectancy, social influence, facilitating conditions directly influence behavioral intention, which makes it a major factor in the Unified Theory of Acceptence and Use of Technology (UTAUT).

Performance expectations are defined as the level of individual trust that using the system will help them to achieve profits in work performance. Business expectations are the level of ease associated with using the system. Social influence is the degree to which individuals feel that other people who are considered important to them believe that they must use the system. While the condition of the facility is a perception to be able to access the resources needed, supported by the knowledge and support needed to use technology. This is also influenced by the lifestyles of users of Vencatesh et al. (2003). Thus Unified Theory of acceptence and Use of Technology can explain user acceptance of e-filing in delivering measured from tax benefits, convenience, amenities, to the support of the user's environment.

Several studies that have tested the Theory of Acceptance and Use of Technology in information systems have been numerous, such as Schaupp (2009) adopting e-files in the US; Al Awadhi and Morris (2009) testing in Kuwait; Cartel et al. (2011) on taxpayers in the US; Ahmad et al. (2013) in Taiwan; Rodrigues et al. (2016) in Dubai. In Indonesia Theory of Acceptance and Use of Technology has been tested by Handayani (2007) on IDX, Wulandari (2016) in Denpasar, Santoso and Setiawan (2017) on e-government, Titasari (2014), Utari (2015), and Zamzami and Putra (2019). Schaupp (2009) examines US taxpayers submitting tax using E-files, finding that performance expectancy, effort expectancy, social influence, and perceived risk have an effect on behavioral intention. The findings of Santoso and Setiawan (2017) on the intention to use the approweb by the Directorate General of Tax account representative are supported by the UTAUT model. However, the findings of Handayani (2007) state that social support does not affect individual intentions in using information systems. In addition Hadayani (2007) also states that the intention of individuals to utilize information systems is still low, thus it will not achieve maximum results. Low utilization of information systems can be motivated by many factors, such as education, work culture, and infrastructure.

Thus this study aims to examine whether there are differences in the acceptance of e-filing in the delivery of taxes between taxpayers on the Java island and the Outside Java Islands by using the UTAUT theory such as performance expectations, effort expectancy, social influence, facilitating conditions. The results of this study can be a consideration of the government whether the development inequality outside and inside Java island can influence the acceptance factors of the e-filing system. So that it can increase public interest using the e-filing system.

\section{LITERATURE REVIEW Unified Theory of Acceptance and Use of Technology (UTAUT)}

Vencatesh et al (2003) developed the new TAM model into the Unified Theory of Acceptance and Use of Technology (UTAUT). The Unified Theory of Acceptance and Use of Technology (UTAUT) describes the user acceptance of information systems combined from eight previous theories, such as Theory of Reasoned Action (TRA), Technology Acceptance Model (TAM), Theory of Planned Behavior (TPB), combination of TAM and TPB models, Motivational Model (MM), Model of PC Utilization (MPCU), Innovatin of Diffusion Theory (IDT), and Social Cognitive Theory (SCT).

Theory of Reasoned Action (TRA) developed by Fishbein and Ajzen (1975) explains that fundamental theories are used to explain human behavior. Davis et al. (1989) explained TRA in individual acceptance using new technology and found that most studies were consistent with the TRA theory in the context of behavior.

TAM is an adaptation of TRA specifically designed to model user perceptions of information systems. The purpose of TAM is to provide an explanation of the determinants of general information technology acceptance, which is able to explain user behavior across the information technology range of end users and user populations (Davis et al. 1989).

In the domain of information systems, Davis et al. (1992) in Venkatesh et al. (2003) apply motivation theory to understand the adoption and use of new technology. Motivational models consist of extrinsic motivation and intrinsic motivation. Extrinsic motivation is the perception of users who want to do activities because they are considered to play an important role in achieving valuable and different results from the activity itself, such as improving job performance, payment, or promotion (Davis et al. 1992 in Venkatesh et al. 2003). Whereas intrinsic motivation is the perception of users who carry out an activity without other 
reasons than the activity process itself (Davis et al. 1992 in Venkatesh et al. 2003).

TPB is a perceived behavioral control theorized to be an additional determinant of intention and behavior. Ajzen (1991) presented a review of several studies that succeeded in using TPB to predict intentions and behavior in various settings. TPB has been successfully applied to understanding individual acceptance and the use of various technologies (in Venkatesh et al., 2003).

The model of PC Utilization (MPCU) derives largely from Triandis' human behavior theory (1977), which presents competing perspectives with those proposed by TRA and TPB. Thompson et al. (1991) in Venkatesh et al. (2003) adapted and refined the Triandis model for the IS context and used a model to predict PC utilization. However, this model is very suitable for predicting individual acceptance and use of various information technologies.

Innovation Diffusion Theory (IDT), Moore and Bensat (1991) adapt the innovation characteristics described by Rogers and refine a set of constructs that can be used to study the acceptance of individual technology and find support for predictive validity of the characteristics of this innovation which consists of relative adventage, ease of use, image, visibility, compatibility, results demonstrability, and voluntariness of use.

Social Cognitive Theory (SCT) According to Bandura SCT is the most powerful theory in explaining human behavior. Compeau and Higgins (1995) in Venkatesh et al. (2003) apply and expand SCT in the context of computer use, the nature of the model and this theory underlies the possibility for the acceptance and use of information technology in general.

The combination of TAM-TPB is a theory that combines TAM with TPB.

\section{Research framework for the Unified Theory of Acceptance and Use of Technology (UTAUT)}

The UTAUT model integrates eight theoretical models consisting of core determinants of the intention to use information systems, which consist of performance expectations, business expectations, social influences, and facility conditions (Venkatesh et al. (2003). The eight theoretical models are empirically tested in four organizations different things such as entertainment, telecommunications, banking, and the public administration industry for six months. UTAUT consists of performance expectations, effort expectancy, social influences, facilitating conditions.

Performance expectations are defined as the level of individual trust that using a system will help to achieve gains in job performance (Venkatesh et al., 2003). Performance expectations are measured by perceptions using e-filing services in terms of benefits, such as saving time, money and effort, facilitating communication with the government, increasing the quality of government services (Shaupp et al. 2009). Constructs of performance expectations for each individual are the strongest predictors in influencing the intention to use new information technology both voluntarily and compulsorily (Venkatesh et al., 2003).

Business expectations are the level of ease associated with using the system. The construct of the business expectations of the UTAUT model consists of perceptions of ease of use, complexity, and ease of use (Venkatesh et al. 2003; in Shaupp et al. 2009). Venkatesh et al. (2003) state that business expectations have a significant effect on the initial use of information technology both mandatory and voluntary, after which it will not affect the period of extended and continuous use.

Social influence is the degree to which individuals feel that other people who are considered important to them believe that they must use the system. The construct of social influence consists of subjective norms, social factors, and images. In compulsory use of technology social influence has a significant effect. This is due to the mandatory context associated with compliance which causes social influences to directly influence the intention to use technology (Venkatesh et al. 2003; in Shaupp et al. 2009).

The condition of the facility is a perception to be able to access the resources needed, supported by the knowledge and support needed to use technology. This is also influenced by the user's lifestyle. Construct conditions of the facility consist of control of perceived behavior, facility conditions, and compatibility (Venkatesh et al. 2003; in Shaupp et al. 2009).

Previous research such as Ahmad et al. (2013) tested the UTAUT model on community intention behavior in using e-government, stating that performance expectations, business expectations, facility conditions, and social influences were factors that influenced the adoption of government service users in Pakistan. Besides that, Chung et al. (2015) stated that the development of the UTAUT model, in addition to fully demonstrating the characteristics of the research subject, identified key factors to facilitate the policy-making process of government institutions responsible for e-government learning. Furthermore, the findings of Rodrigues et al. (2016) the results cannot identify significant differences in the application of e-government between expatriates and USA citizens, or between users of different education levels.

In Indonesia, like Hakim (2016) modified the model of Venkatesh et al. (2003) found that the influence of expectations of performance and social influence on behavioral intentions, as well as the influence of behavioral intention on actual use in men, was stronger than in women. Conversely, the influence of business expectations on behavioral intentions and supporting facilities or support for actual use in women has a stronger influence. In addition, in the age group, the effect on all variables studied turned out to be stronger in the age group 25-35 years. Santoso and Setiwan (2017) combine the UTAUT model with the belief of using the web, security controls, and perceptions of the intention to use Approweb stating that performance expectations, business expectations, social influences, perceived security controls positively influence the intention to use Approweb. The results of existing studies support the findings of Venkatesh et al. (2003).

Based on the results of previous studies, it can be stated that the UTAUT model has an influence on the use of e-filing in reporting taxes in Indonesia, which is currently still in the voluntary stage and does not allow its use someday. But there is still no one testing the differences in taxpayers' receipts on 
Java and the Outer Islands of Java. As stated by Rosmeli and Nurhayani (2014) that development in Indonesia is still centered on the island of Java. Inequality in Java is caused by infrastructure that has an impact on economic activities and affects per capita income which will improve the quality of education and health which has an impact on the quality of human resources. As stated in social cognitive theory that changes in social life, economics, and technological development will improve individual qualities from previous lives (Bandura, 1989). Thus development that is not evenly distributed will make the quality of human resources also uneven, especially in the acceptance of new technology such as the e-filing system in tax reporting. As stated by Tarmidi (2017) that the limitations of Information Technology and the Internet even in Indonesia, resulting in uneven application of knowledge and the implementation of e-filing tax by the taxpayer in the country.

Based on the above framework, conclusions can be drawn from the hypothesis as follows:

H1: There are differences in performance expectancy between taxpayers in Java and outside Java.

H2: There are differences in effort expectancy between taxpayers in Java and outside Java.

H3: There are differences in social influence between taxpayers in Java and outside Java.

H4: There are differences in facilitating conditions between taxpayers in Java and outside Java.

H5: There are differences in behavioral intention to use efiling between taxpayers in Java and outside Java.

\section{RESEARCH METHOD}

This research is comparative research, which examines the average difference of each pair and identifies the differences in groups tested (Cooper and Schindler, 2011). The purpose of this comparative study is to find the difference between the mean values can detect if there are indeed differences from the groups tested. Sampling of this study is nonprobability sampling, namely purposive sampling. The sample used in this study is taxpayers who use e-filing in reporting taxes in Indonesia, which will be divided into two groups of taxpayers on Java and outside Java. The size of the sample according to Hair et al. (2010) to be able to maintain power up to 0.80 percent, a 5: 1 sample is needed, which is between 15 and 20 data observations for each independent variable.

The data collection period is two weeks using a questionnaire. Questionnaires are distributed online using google forms, google form links are sent through whatsApp groups. There were 263 responses from the Indonesian people, but only 255 could be analyzed. This is caused by respondents not fulfilling requirements such as education and do not yet have a Taxpayer Identification Number. 166 of them were responded to by the Indonesian people on the Java Island and 89 outside the Java Island.

Characteristics of respondents include gender, age, education, and income. Majority of respondents both in and outside Java is a woman with a percentage of 51 percent in Java and 52 percent outside Java. Majority of respondents aged 20-30 years, In Java the percentage of respondents aged 20-30 years was 39 percent. While the age of respondents outside of Java, aged 20-30 years was 50 percent. Education of respondents was postgraduate in Java as much as 59 percent and outside of Java as much as 64 percent. Majority of respondents' income ranged from Rp3.000.000 to Rp6.000.000 both in Java and outside Java. On Java as much as 34 percent and outside of Java as much as 45 percent.

Tabel 1 Characteristics of respondents

\begin{tabular}{|c|c|c|c|c|c|}
\hline \multirow{2}{*}{\multicolumn{2}{c|}{ Information }} & \multicolumn{2}{c|}{ In Java Island } & \multicolumn{2}{c|}{ Outside of Java Island } \\
\cline { 2 - 6 } Gender & & Total & Percentage & Total & Percentage \\
\cline { 2 - 6 } & female & 82 & 49,40 & 43 & 48,31 \\
\hline \multirow{4}{*}{ Age } & $<20$ & 7 & 50,60 & 46 & 51,69 \\
\cline { 2 - 6 } & $20-30$ & 65 & 39,16 & 4 & 5,62 \\
\cline { 2 - 6 } & $31-40$ & 42 & 25,30 & 30 & 50,56 \\
\cline { 2 - 6 } & $41-50$ & 32 & 19,28 & 7 & 33,71 \\
\cline { 2 - 6 } & $51-60$ & 17 & 10,24 & 2 & 2,25 \\
\cline { 2 - 6 } & $60>$ & 3 & 1,81 & 0 & 0,00 \\
\hline \multirow{4}{*}{ Education } & SHS & 13 & 7,83 & 5 & 5,62 \\
\cline { 2 - 6 } & Diploma & 0 & 0,00 & 1 & 1,12 \\
\cline { 2 - 6 } & Bachelor & 35 & 21,08 & 26 & 29,21 \\
\cline { 2 - 6 } & Postgraduate & 98 & 59,04 & 57 & 64,04 \\
\cline { 2 - 6 } & Doctoral & 20 & 12,05 & 0 & 0,00 \\
\hline \multirow{5}{*}{ Income } & $<3.000 .000$ & 51 & 30,72 & 34 & 38,20 \\
\cline { 2 - 6 } & $3.000 .001-6.000 .000$ & 56 & 33,73 & 40 & 44,94 \\
\cline { 2 - 6 } & $6.000 .001-9.000 .000$ & 26 & 15,66 & 9 & 10,11 \\
\cline { 2 - 6 } & $9.000 .001-12.000 .000$ & 14 & 8,43 & 3 & 3,37 \\
\cline { 2 - 6 } & $12.000 .001-15.000 .000$ & 9 & 5,42 & 2 & 2,25 \\
\cline { 2 - 6 } & $>15.000 .001$ & 10 & 6,02 & 1 & 1,12 \\
\hline
\end{tabular}

Source: processed data using Mc. excel 2013 


\section{Measurements}

Taxpayers are individuals who have a taxpayer identification number and the obligation to pay income taxes earned in the region of Indonesia. Taxpayers are measured using a categorical scale, 1 for taxpayers in Java, and 2 for taxpayers outside Java.

Peformance Expectancy (PE) are defined as the level of individual trust that using an e-filing system will help them to achieve profits in reporting taxes. The question item was adopted from Venkatesh et al. (2003) as many as 3 question items. Then modified according to the needs of this study. The measurement scale uses a Likert scale type 5 points, from 1 "strongly disagree" to 5 "strongly agree". The results of data processing showed that the value of Cronbach's alpha was 0,885314 and composite reliability was 0,928814 , that were more than 0.7 . Thus the measuring instruments used in this study have good accuracy, consistency, and accuracy in making measurements.

Effort Expectacy (EE) are the level of convenience associated with using the e-filing system in reporting taxes. Item questions were adopted from Venkatesh et al. (2003) as many as 3 question items. Then modified according to the needs of this study. The measurement scale uses a Likert scale type 5 points, from 1 "strongly disagree" to 5 "strongly agree". The results of data processing showed that the value of Cronbach's alpha was 0,911498 and composite reliability was 0,944407 , that were more than 0,7 . Thus the measuring instruments used in this study have good accuracy, consistency, and accuracy in making measurements.

Social Influence (SI) is the extent to which individuals feel that other people who are considered important to them believe that they must use the e-filing system in reporting taxes. The question item was adopted from Venkatesh et al. (2003) as many as 4 question items. Then modified according to the needs of this study. The measurement scale uses a Likert scale type 5 points, from 1 "strongly disagree" to 5 "strongly agree". The results of data processing showed that the value of Cronbach's alpha was 0,714975 and composite reliability was 0,80743 , that were more than 0.7. Thus the measuring instruments used in this study have good accuracy, consistency, and accuracy in making measurements.

Facilitating Condition (FC) is a perception to be able to access the resources needed, supported by the knowledge and support needed to use e-filing in reporting SPT. The question item was adopted from Venkatesh et al. (2003) as many as 4 question items. Then modified according to the needs of this study. The measurement scale uses a Likert scale type 5 points, from 1 "strongly disagree" to 5 "strongly agree". The results of data processing showed that the value of Cronbach's alpha was 0,746287 and composite reliability was 0,855084 , that were more than 0.7 . Thus the measuring instruments used in this study have good accuracy, consistency, and accuracy in making measurements.

Behavioral Intention (BI) is the intention of individuals to use e-filing to report SPT. The question item was adopted from Venkatesh et al. (2003) as many as 3 question items. Then modified according to the needs of this study. The measurement scale uses a Likert scale type 5 points, from 1 "strongly disagree" to 5 "strongly agree". The results of data processing showed that the value of Cronbach's alpha was 0,944428 and composite reliability was 0,96428 , that were more than 0.7 . Thus the measuring instruments used in this study have good accuracy, consistency, and accuracy in making measurements.

\section{RESEARCH RESULT T test}

A different t-test is used to determine whether two unrelated samples have different mean values. Table 2 shows the average value of respondents' answers in Java and outside Java regarding the intention to use e-filing in reporting taxes using UTAUT. UTAUT is seen from indicators of performance expectancy, effort expectancy, social influence, facilitating conditions, and behavioral intention. The results of the analysis show that performance expectancy, effort expectancy, social influence, facilitating conditions, and behavioral intention do not have significantly different mean for the use of e-filing system in reporting taxes between respondents who live in Java and those who live outside the island Java.

Table 2 Group Statistics

\begin{tabular}{|c|c|c|c|c|c|c|}
\hline & Islands & $\mathbf{N}$ & $\begin{array}{c}\text { Theorical } \\
\text { Mean }\end{array}$ & $\begin{array}{c}\text { Actual } \\
\text { Mean }\end{array}$ & $\begin{array}{c}\text { Std. } \\
\text { Deviation }\end{array}$ & $\begin{array}{c}\text { Std. } \\
\text { Error } \\
\text { Mean }\end{array}$ \\
\hline \multirow{2}{*}{ PE } & 1 & 166 & 9 & 12,06 & 2,789 &, 216 \\
\cline { 2 - 7 } & 2 & 89 & 9 & 12,20 & 2,594 &, 275 \\
\hline \multirow{2}{*}{ EE } & 1 & 166 & 9 & 11,36 & 2,869 &, 223 \\
\cline { 2 - 7 } & 2 & 89 & 9 & 11,55 & 2,509 &, 266 \\
\hline \multirow{2}{*}{ SI } & 1 & 166 & 12 & 13,34 & 3,713 &, 288 \\
\cline { 2 - 7 } & 2 & 89 & 12 & 13,47 & 3,504 &, 371 \\
\hline \multirow{2}{*}{ FC } & 1 & 166 & 9 & 11,12 & 2,837 &, 220 \\
\cline { 2 - 7 } & 2 & 89 & 9 & 11,06 & 2,578 &, 273 \\
\hline \multirow{2}{*}{ BI } & 1 & 166 & 9 & 12,02 & 2,917 &, 226 \\
\cline { 2 - 6 } & 2 & 89 & 9 & 11,97 & 2,866 &, 304 \\
\hline
\end{tabular}


Table 3 Indenpendent sample T test

\begin{tabular}{|c|c|c|c|c|c|c|c|c|c|c|}
\hline & \multicolumn{2}{|c|}{$\begin{array}{c}\text { Levene's Test } \\
\text { for Equality of } \\
\text { Variances } \\
\end{array}$} & \multicolumn{7}{|c|}{ t-test for Equality of Means } \\
\hline & & \multirow[t]{2}{*}{$\mathbf{F}$} & \multirow[t]{2}{*}{ Sig. } & \multirow[t]{2}{*}{$\mathbf{t}$} & \multirow[t]{2}{*}{ df } & \multirow[t]{2}{*}{$\begin{array}{l}\text { Sig. (2- } \\
\text { tailed) }\end{array}$} & \multirow[t]{2}{*}{$\begin{array}{c}\text { Mean } \\
\text { Difference }\end{array}$} & \multirow[t]{2}{*}{$\begin{array}{l}\text { Std. Error } \\
\text { Difference }\end{array}$} & \multicolumn{2}{|c|}{$\begin{array}{c}\text { 95\% Confidence } \\
\text { Interval of the } \\
\text { Difference }\end{array}$} \\
\hline & & & & & & & & & Lower & Upper \\
\hline \multirow[t]{2}{*}{$\mathrm{PE}$} & $\begin{array}{l}\text { Equal variances } \\
\text { assumed }\end{array}$ & 0,235 & 0,628 & $-0,397$ & 253 & 0,692 & $-0,142$ & 0,358 & $-0,847$ & 0,562 \\
\hline & $\begin{array}{c}\text { Equal variances not } \\
\text { assumed }\end{array}$ & & & $-0,406$ & 191,592 & 0,685 & $-0,142$ & 0,350 & $-0,832$ & 0,548 \\
\hline \multirow[t]{2}{*}{$\mathrm{EE}$} & $\begin{array}{l}\text { Equal variances } \\
\text { assumed }\end{array}$ & 2,314 & 0,129 & $-0,524$ & 253 & 0,601 & $-0,189$ & 0,361 & $-0,900$ & 0,522 \\
\hline & $\begin{array}{c}\text { Equal variances not } \\
\text { assumed }\end{array}$ & & & $-0,545$ & 201,752 & 0,586 & $-0,189$ & 0,347 & $-0,873$ & 0,495 \\
\hline \multirow[t]{2}{*}{ SI } & $\begin{array}{l}\text { Equal variances } \\
\text { assumed }\end{array}$ & 0,548 & 0,460 & $-0,281$ & 253 & 0,779 & $-0,135$ & 0,478 & $-1,077$ & 0,808 \\
\hline & $\begin{array}{c}\text { Equal variances not } \\
\text { assumed }\end{array}$ & & & $-0,286$ & 189,298 & 0,775 & $-0,135$ & 0,470 & $-1,062$ & 0,793 \\
\hline \multirow[t]{2}{*}{$\mathrm{FC}$} & $\begin{array}{l}\text { Equal variances } \\
\text { assumed }\end{array}$ & 0,879 & 0,349 & 0,178 & 253 & 0,859 & 0,064 & 0,361 & $-0,647$ & 0,776 \\
\hline & $\begin{array}{c}\text { Equal variances not } \\
\text { assumed }\end{array}$ & & & 0,183 & 195,425 & 0,855 & 0,064 & 0,351 & $-0,628$ & 0,756 \\
\hline \multirow[t]{2}{*}{$\mathrm{BI}$} & $\begin{array}{l}\text { Equal variances } \\
\text { assumed }\end{array}$ & 0,087 & 0,769 & 0,152 & 253 & 0,880 & 0,058 & 0,381 & $-0,692$ & 0,808 \\
\hline & $\begin{array}{c}\text { Equal variances not } \\
\text { assumed }\end{array}$ & & & 0,153 & 182,807 & 0,879 & 0,058 & 0,379 & $-0,690$ & 0,805 \\
\hline
\end{tabular}

Source: processed data using SPSS 25

The results of the analysis in table 3 show the value of the $f$ count levene's test of the performance expectancy indicator is 0.235 , with a probability value of 0.628 greater than 0.05 , it can be concluded that $\mathrm{HO}$ is accepted or has a different variance. Thus, the different t-test uses equal variances not assumed. The $\mathrm{t}$ test value is 0.406 with a probability of 0.685 . So $\mathrm{H} 1$ is not supported, meaning that the average performance expectancy of respondents who live in Java with those who live outside of Java is not significantly different. The value of the $f$ count levene's test of the effort expectancy indicator is 2.314 , with a probability value of 0.129 which is greater than 0.05 , it can be concluded that $\mathrm{H} 0$ is accepted or has a different variance. Thus, the different $t$ test uses equal variances not assumed. The $t$ test value is 0.545 with a probability of 0.586 . So $\mathrm{H} 2$ is not supported, meaning that the average effort expectancy of respondents who live in Java and those who live outside of Java is not significantly different. The value of the $f$ count levene's test of the social influence indicator is 0.548 , with a probability value of 0.460 which is greater than 0.05 , it can be concluded that $\mathrm{H} 0$ is accepted or has a different variance. Thus, the different t-test uses equal variances not assumed. The t test value is 0.286 with a probability of 0.775 . So $\mathrm{H} 3$ is not supported, meaning that the average social influence of respondents who live in Java with those who live outside of Java is not significantly different. The value of the $\mathrm{f}$ count levene's test of the facilitating condition indicator is 0.879 , with a probability value of 0.349 which is greater than 0.05 , it can be concluded that $\mathrm{HO}$ is accepted or has a different variance. Thus, the different $\mathrm{t}$-test uses equal variances not assumed. The $\mathrm{t}$ test value is 0,183 with a probability of 0,585 . So $\mathrm{H} 4$ is not supported, meaning that the average facilitating condition of respondents living in Java with those living outside Java is not significantly different. The value of the $f$ count levene's test of the behavioral intention indicator is 0.087 , with a probability value of 0.769 which is greater than 0.05 , it can be concluded that $\mathrm{H} 0$ is accepted or has a different variance. Thus, the different $t$-test uses equal variances not assumed. The $t$ test value is 0.153 with a probability of 0.879 . So H5 is not supported, meaning that the average behavioral intention of respondents who live in Java with those who live outside of Java is not significantly different.

\section{DISCUSSION}

Devos (2014) quoted by Tarmidi (2017) states that the Tax Compliance Theory is divided into two approaches, namely: 1) Economic detterance approach which is carried out by considering external factors of the Taxpayer such as the taxation system, legal certainty, Government services and other external factors and 2) Psychological approach that is done by considering the psychological of the Taxpayer himself internally, such as the perception of the Taxpayer, internal knowledge, awareness and other internal factors so that it can influence to become an Obedient Taxpayer. UTAUT is formed 
from eight theories which are supported by external and internal concepts of technology users.

Therefore, this study looks at the difference whether there is a difference in the acceptance of technological development from tax reporting using e-filing between taxpayers in Java and outside Java. However, the results of the study stated that there were no differences in performance expectancy, effort expectancy, social influence, facilitating conditions, and behavioral intention of taxpayers in using efiling both in Java and outside Java. Taxpayers in Java and outside Java both feel that using e-filing can facilitate tax reporting. This can be seen from the average respondents on the island of Answer and outside Java exceeding the theoretical mean of 12.06 of taxpayers on the island of Java and 12.20 outside the island of Java. In addition to using the efiling system itself is not so difficult for respondents. This can be seen from the ease of use of e-filing, thus not requiring great effort to use the system for taxpayers. The closest parties and facilities also influence respondents in using e-filing and there are no differences in responses for taxpayers who are in Java and outside Java. When asked for further wishes to use efiling in the future, still intend to use it. As seen from the average actual behavioral intention. This may come required by the government to use e-filing in reporting taxes. In general, this study does not support what Rosmeli and Nurhayani (2014) and Tarmidi (2017) state that development in Indonesia is still centered on the island of Java and limitations of Information Technology and the Internet in Indonesia, resulting in uneven application of knowledge and the implementation of e-filing tax by the taxpayer in the country.

\section{CONCLUSION}

The development of technology and the internet has changed many government systems, including taxation. Indonesia has implemented online tax reporting known as efiling. It is expected that its use can facilitate and save time in reporting taxes. However, the unequal development and development of technology and the internet in Indonesia can affect taxpayers in receiving e-filing. Therefore, this study examines differences in taxpayers' acceptance of e-filing using UTAUT to tax authorities in Java and outside Java. The results state that there is no significant difference between taxpayers in Java and outside Java in accepting e-filing as an online tax reporting system from performance expectancy, effort expectancy, social influence, facilitating conditions, and behavioral intention. Thus, inequality of development and internet services can be felt by all taxpayers throughout Indonesia.

\section{LIMITATION AND SUGGESTION}

This research uses the google form link to distribute questionnaires, so data that cannot be controlled properly. Thus the number of respondents between outside Java and inside Java is not balanced. It is recommended that further researchers be able to manage the distribution of questionnaires so that they can be balanced when conducting comparative research. The use of UTAUT theory is still too shallow to compare development inequality in Indonesia. It might be possible to add variables based on the theory revealed by Devos (2014) cited by Tarmidi (2017) stating that the Tax Compliance Theory is divided into two approaches, namely: 1) Economic detterance approach and 2) Psychological approach as a whole using qualitative methods in order to compare directly. Thus it can be useful in developing systems and increasing state revenues from taxes.

\section{BIBLIOGRAPHY}

1. Santoso, W. Nanang and Setiawan Doddy. 2017. Faktor-faktor yang Mempengaruhi Niat Penggunaan Approweb oleh Account Representative Direktorat Jenderal Pajak. Jurnal Akuntansi, Vol. XXI, no.02, pp. 232-252.

2. Davis, Fred D.; Bagozzi, Richard P.; Warshaw, Paul R. 1989. User Acceptance Of Computer Technology: A Comparison Of Two. Management Science, 35, 8 pg. 982

3. Davis, Fred D..1989. Perceived Usefulness, Perceived Ease of Use, and User Acceptance of Information Technology. MIS Quarterly, Vol. 13, No. 3; pp. 319-340

4. Venkatesh, Viswanath, Davis, Fred D. 1996. A model of the antecedents of perceived ease of use: Development and test. Decision Sciences, 27 (3).

5. Venkatesh, Viswanath; Davis, Fred D. 1996. A model of the antecedents of perceived ease of use: Development and test. Decision Sciences, 27, 3; pg. 451

6. Schaupp, L. C., \& Hobbs, J. (2009). E-File Adoption : A Study of $U . S$. Taxpayers Intentions. Proceedings of the 42nd Hawaii International Conference on System Sciences, 1-10.

7. Venkatesh, V., Morris, M. G., Hall, M., Davis, G. B., Davis, F. D., \& Walton, S. M. (2003). User Acceptance Of Information Technology: Toward A Unified View. MIS Quarterly, 27(3), 425-478.

8. Jackson, Cynthia M,Simeon Chow, and Robert A. bitch.1997. Toward an Understanding of the Behavioral Intention to Use an Information System. Decision sciences Volume 28 Number 2.

9. Cooper, Donald R. (2011). Business Research Methods. Australia: McGraw-Hill

10. Hair, Joseph et al. (2010). Multivariate Data Analysis. New Jarsey: Prentice Hall.

11. Thompson, R. L., Higgins, C. A. and Howell, J. M. (1991) Personal computing: toward a conceptual model of utilization. MIS quarterly, 125-143.

12. Titisari, A. (2014) Analisis Faktor Perilaku dan Tingkat Kesadaran Wajib Pajak Terhadap Niat Menggunakan eFilling (Studi Empiris Pada Wajib Pajak Badan). Universitas Gadjah Mada, Yogyakarta.

13. Utari, S. (2015) Pengaruh Kepercayaan Wajib Pajak Terhadap penggunaan e-Filling. Universitas Gadjah Mada, Yogyakarta

14. Ahmad, M. O., Markkula, J. and Oivo, M. (2013) "Factors affecting e-government adoption in Pakistan: a citizen's perspective”. Transforming Government: People, Process and Policy, 7(2), 225-239.

15. Al Awadhi, S. and Morris, A. (2008) The Use of the UTAUT Model in the Adoption of E-government Services in Kuwait. Paper presented at the The 41st Annual Hawaii International Conference on System Sciences, Waikoloa, Big Island, HI, USA.

16. Chung, H.-Y., Lee, G.-G. and Kuo, R.-Z. (2015) Determinants of Public Servants' Intention to Adopt EGovernment Learning. Review of Public Personnel Administration, forthcoming. 
ISSN (Online): 2455-3662

EPRA International Journal of Multidisciplinary Research (IJMR) - Peer Reviewed Journal

Volume: 6 | Issue: 4 | April 2020 || Journal DOI: 10.36713/epra2013 || SJIF Impact Factor: 5.614||ISI Value: 1.188

17. Rodrigues, G., Sarabdeen, J. and Balasubramanian, $S$. (2016) "Factors that Influence Consumer Adoption of Egovernment Services in the UAE: A UTAUT Model Perspective". Journal of Internet Commerce, 15(1), 18-39.

18. Hakim, M. Malik. 2016. Analisis Model Penerimaan Pengguna Sistem Pelaporan Pajak Online. Jurnal Simetris, Vol.7 no. 1.

19. Ngadiman.2008. Modernisasi dan Reformasi Peayanan Perpajakan.MIIPS, Vol. 7. no. 2.pp:165-175.

20. Ariefana, Pebriansyah. 2018. April 2018, Ditjen Pajak Tak Layani SPT Manual, Harus e-filing https://www.suara.com/bisnis/2018/03/09/184200/april-2018ditjen-pajak-tak-layanin-spt-manual-harus-e-filing (diakses pada 15 November 2018).
21. https://www.indonesia.go.id/archipelago

22. Tarmidi, Deden; Giawan Nur Fitria; and Sri Purwaningsih.2017. Analisis Kepatuhan Pajak: Persepsi Wajib Pajak Terhadap E-Filling. Media Akuntansi Perpajakan, Vol. 2, No. 2,pp: 9-22

23. Zamzami, Annisa $H$ and Putra, Y.M.2019. Intensity of Taxpayers Using E-Filing (Empirical Testing of Taxpayers in Jakarta, Bogor, Depok, Tangerang, and Bekasi). International Journal of Multidisciplinary Research, Vol. 5(7), pp.

24. Rosmeli and Handayani.2014. Studi Komperatif Ketimpangan Wilayah Antara Kawasan Barat Indonesia dan Kawasan Timur Indonesia. Mankeu, Vol 3 no. 1, pp. 374-463. 